Rev. Bras. Saúde Prod. Anim., Salvador, v.16, n.3, p.658-666 jul./set.., $2015 \quad \underline{\text { http://www.rbspa.ufba.br }}$

\title{
Roof pitch and exposure and different roofing materials in reduced models of animal production facilities in the fall and winter
}

\author{
Inclinação e exposição de telhado e diferentes materiais de cobertura em modelos \\ reduzidos de instalação zootécnica no outono e inverno
}

\section{MELO, Thiago Vasconcelos ${ }^{1 *}$; FURLAN, Renato Luís ${ }^{2}$; MILANI, Adhemar Pitelli ${ }^{3}$; BUZANSKAS, Marcos $\mathrm{Eli}^{4}$; MOURA, Adolpho Marlon Antoniol de ${ }^{5}$; MOTA, Diego} Azevedo ${ }^{6}$

${ }^{1}$ Universidade Federal dos Vales do Jequitinhonha e Mucuri, Instituto de Ciências Agrárias, Unaí, Minas Gerais, Brasil.

${ }^{2}$ Universidade Estadual Paulista Júlio de Mesquita Filho, Departamento de Morfologia e Fisiologia Animal, Jaboticabal, São Paulo, Brasil.

${ }^{3}$ Universidade Estadual Paulista Júlio de Mesquita Filho, Departamento de Engenharia Rural, Jaboticabal, São Paulo, Brasil.

${ }^{4}$ Universidade Estadual Paulista Júlio de Mesquita Filho, Departamento de Ciências Exatas, Jaboticabal, São Paulo, Brasil.

${ }^{5}$ Fundação Oswaldo Cruz, Centro de Criação de Animais de Laboratório, Rio de Janeiro, Brasil.

${ }^{6}$ Universidade Federal da Fronteira Sul, Colegiado de Agronomia, Erechim, Rio Grande do Sul, Brasil.

*Endereço para correspondência: thiago.melo@ufvjm.edu.br

\section{SUMMARY}

The objective was to verify the influence of roof pitch, exposure and roofing material on the internal temperature of reduced models of animal production facilities. For the development of the research, 48 reduced models with dimensions $1.00 \times 1.00 \times 0.50 \mathrm{~m}$ were used. The roof was shed-type, and models faced the North or South directions, with 24 models for each side of exposure. Ceramic, galvanizedsteel and fibro tiles were used to build the roofs. Pitches varied between $20 ; 30 ; 40$ and $50 \%$ for the ceramic tile and $10 ; 30 ; 40$ and $50 \%$ for the other two. Inside the model, temperature readings were performed at every hour, for 12 months. The results were evaluated in a general linear model in a nested $3 \times 4 \times 2$ factorial arrangement. As the roof pitch increased, the internal temperature within the model dropped, so utilizing sharper pitches $(50 \%)$ for ceramic and fibro roofs with a larger area facing the South can provide lower temperatures within the animal production facilities. In regions where the cold is more stressful than the heat, having animal production facilities with larger roof exposure to the North may minimize the losses caused by cold stress.

Keywords: ambience, aviculture, heat, shed

\section{RESUMO}

Objetivou-se verificar a influencia da inclinação, exposição e tipo de material de cobertura sobre a temperatura interna de modelos reduzidos de instalação zootécnica, em condições ambientais das coordenadas geográficas " $21^{\circ} 14^{\prime} 05$ de latitude sul e $48^{\circ} 17^{\prime} 09^{\prime \prime}$ de longitude oeste. Para o desenvolvimento da pesquisa foram utilizados 48 modelos reduzidos nas dimensões de $1,00 \mathrm{x}$ $1,00 \times 0,50$ metros. A cobertura foi de uma água, dispostos nas exposições Norte-Sul, sendo 24 modelos para cada face de exposição. Foram utilizadas na cobertura, telha de cerâmica, aço galvanizado e fibrocimento. Os níveis de inclinação foram de $20 ; 30 ; 40$ e $50 \%$ para telha de cerâmica e de $10 ; 30 ; 40$ e $50 \%$ para as demais. No interior dos modelos foram realizadas leituras de temperatura, a cada hora durante 12 meses. Os resultados obtidos foram avaliados num modelo linear geral no esquema fatorial aninhado $3 \times 4 \times 2$. As médias obtidas foram comparadas pelo teste de Tukey a $5 \%$ de probabilidade. Com o aumento da inclinação do telhado, a temperatura interna dentro do modelo reduziu, de modo que inclinações mais acentuadas $(50 \%)$ para coberturas de cerâmica e fibrocimento, com uma maior exposição de cobertura para o sul, pode proporcionar 
Rev. Bras. Saúde Prod. Anim., Salvador, v.16, n.3, p.658-666 jul./set.., $2015 \quad \underline{\text { http://www.rbspa.ufba.br }}$ ISSN 15199940

temperaturas mais baixas dentro das instalações zootécnicas. Em regiões onde o frio é mais estressante do que o calor, as instalações com maior exposição de cobertura para o Norte pode minimizar as perdas causadas pelo estresse causado pelo frio.

Palavras-chave: ambiência, avicultura, calor, galpão

\section{INTRODUCTION}

The animal production facility is aimed at providing comfort and protection to the animals for increased productivity. The constructions are directly exposed to the weather conditions, and so they must be built so as to reduce the environmental variables that negatively interfere with the welfare and performance of animals.

Conducting research on animal production facilities on a natural scale is costly and not very practical, which has led researchers such as Hann et al. (1961), Forehlich et al. (1975) and Celis \& Jara (1990) to utilize distorted-scale models in their experiment involving this matter. In addition to reproducing the characteristics and thermal responses of natural facilities, these models reduce the experimental costs.

Among the many research studies applied in animal production facilities, those involving roof pitches are scarce, and the quantification of the incoming solar radiation on the pitched surfaces in relation to the flat surface, at different angles, is used in a large variety of applications (solar panels, architecture projects, agronomic research and micrometeorological studies). According to Coan et al. (2012), the total radiation hitting a surface varies according to the exposure and declivity.

Thus, the objective of this study was to verify the influence of pitch and the North- and South-exposure of ceramic, galvanized-steel and fibro tiles on the internal temperature of reduced models of animal production facilities during the fall and winter.

\section{MATERIAL AND METHODS}

The experiment was conducted at the Department of Rural Engineering and the Department of Animal Morphology and Physiology of the Faculty of Agrarian and Veterinary Sciences (FCAV/UNESP), located in Jaboticabal, SP, Brazil. During the trial period, the average temperature was $22,6^{\circ} \mathrm{C}$, maximum temperature of $30,1^{\circ} \mathrm{C}$ and a minimum of $17,0^{\circ} \mathrm{C}$, with an average rainfall of $1225 \mathrm{~mm}$. Forty-eight reduced models with dimensions $1.00 \times 1.00 \times$ $0.50 \mathrm{~m}$ were built, thereby having the same air volume as the interior of all models. Wooden rods of different sizes were built to incline them. The material utilized was plywood with $6.0 \mathrm{~mm}$ of thickness on the sides and on the bottom so as to avoid the effect of the climate variables from outdoors as much as possible, so that the alterations in the internal environment did not undergo major effects originated from the roof.

The reduced models of plywood were painted with waterproof white paint to increase their reflectivity and endurance against weathering. Roofs were shedlike. Half of the models faced the North, and the other 24 faced the South direction, with two replications per pitch. The models were covered with $0.5 \mathrm{~mm}$ tick roman ceramic; $0.5 \mathrm{~mm}$ thick galvanized steel; and $6.00 \mathrm{~mm}$ thick fibro tiles. The pitches of the roofs varied between $20 ; 30 ; 40$ and $50 \%$ for the ceramic tile and 10;30; 40 and 50\% for the others. The pitch of $10 \%$ was not used in the ceramic roof because according to the technical engineering 
specifications, ceramic tiles cannot be set up with pitches lower than $20 \%$. The models were built on the Campus of UNESP Jaboticabal, located at $21^{\circ} 14^{\prime} 05^{\prime \prime}$ South latitude, $48^{\circ} 17^{\prime} 09^{\prime \prime}$ West longitude and $615.01 \mathrm{~m}$ altitude, utilizing an area of $160 \mathrm{~m}^{2}$ (Agro meteorological station of the Rural Engineering Department FCAV/UNESP).

Was evaluated the ceramic, galvanized steel and fibro tiles and different roof pitches and their (North/South) exposure as to their influence on the internal temperature. The data on the external environment of the experiment were collected by a conventional, automated meteorological station at the Department of Exact Sciences of UNESP/Jaboticabal. To obtain the data on the internal temperature of the models, one type $\mathrm{T}$ thermocouple model $105 \mathrm{~T}$ with accuracy of $\pm 1{ }^{\circ} \mathrm{C}$ was properly positioned at the center of the model and another at two centimeters below the roof, held by wood supports. The data on internal temperature of the models were read at every hour, for one year, using data acquisition system Datalogger (Campbell Scientific Inc).
After collecting the data for one year, they were filtered to exclude the days that had a ratio of insolation above $85 \%$ (obtained from the meteorological station of Department of Exact Sciences of UNESP/Jaboticabal) so as to avoid the cloudy and rainy days.

From the dataset, one critical winter day was selected for analysis of the variation of temperature throughout the day according to the pitches, roofing materials and exposures. The estimated solar radiation data were collected at the Meteorological Station of the Department of Rural Engineering of FCAV/UNESP in a structure called "Experimental Watershed", described in detail by Turco \& Rizzatti (2006). The results were evaluated in a General linear model by statistical package SAS version 9.1 (SAS, 2001) on a nested $3 \times$ $4 \times 2$ factorial arrangement for the roofing material, roof pitch and North/South exposure values, respectively. The effects of roofing material and exposure, however, were nested in the pitch factor. The means were compared by the Tukey test at 5\% of probability by following the statistical model below:

$$
Y i j k l=m+C i+E j+C E(i j)+I k:(C i E j)+e i j k l
$$

Where:

Yijkl = observation of roof $i$, with pitch $\mathrm{j}$ and exposure $\mathrm{k}$;

$\mathrm{m}=$ overall mean;

$\mathrm{Ci}=$ effect of roofing material $\mathrm{i}$, where $\mathrm{i}$

$=1,2,3$;

$E j=$ effect of exposure $\mathrm{j}$, where $\mathrm{j}=1,2$; $\mathrm{CE}(\mathrm{ik})=$ effect of the interaction between roofing material $i$ and exposure $\mathrm{j}$;

Ik : $(\mathrm{CiEj})=$ effects of the interaction pitch $\mathrm{k}$ nested between roofing material $\mathrm{i}$ and exposure $\mathrm{j}$; and

eijk $=$ error associated with each observation.

\section{RESULTS AND DISCUSSION}

When the pitch of the South-facing roof is increased, there was a decrease in the incoming global solar radiation (Table 1 ), which is due to the lower incidence of estimated global solar radiation on pitched surfaces facing the South.

During the critical winter days, there was a more marked difference in temperature variation as regards the North- and South-facing roofs (Figures 
Rev. Bras. Saúde Prod. Anim., Salvador, v.16, n.3, p.658-666 jul./set.., $2015 \quad \underline{\text { http://www.rbspa.ufba.br }}$ ISSN 15199940

1, 2 and 3), because the inclination of the sun changes throughout the year, and is maximized in the fall and winter. This demonstrates that the incidence of incoming solar radiation in the fall and winter in the North-facing roof is much higher. This fact can be of great importance, especially in the starter phases of poultry and pig rearing, or in areas that have very low temperature averages like certain regions in the south of Brazil.

Table 1. Estimated global solar radiation for the pitches of 10, 20, 30, 40 and $50 \%$ on the North (N)- and South (S)-facing roofs during the hottest day of the experimental period in Jaboticabal city

\begin{tabular}{lcccccccccc}
\hline \multicolumn{10}{c}{ Estimated radiation $\left(\mathrm{cal} / \mathrm{cm}^{2} /\right.$ day $)$} \\
\hline Station & $10 \mathrm{~N}$ & $10 \mathrm{~S}$ & $20 \mathrm{~N}$ & $20 \mathrm{~S}$ & $30 \mathrm{~N}$ & $30 \mathrm{~S}$ & $40 \mathrm{~N}$ & $40 \mathrm{~S}$ & $50 \mathrm{~N}$ & $50 \mathrm{~S}$ \\
Fall & 503.8 & 413.8 & 541.3 & 365.2 & 572.5 & 315.9 & 597.4 & 267.6 & 616.3 & 221.5 \\
Winter & 495.9 & 422.8 & 524.8 & 380.9 & 547.8 & 337.4 & 565.2 & 293.9 & 577.3 & 251.6 \\
\hline
\end{tabular}

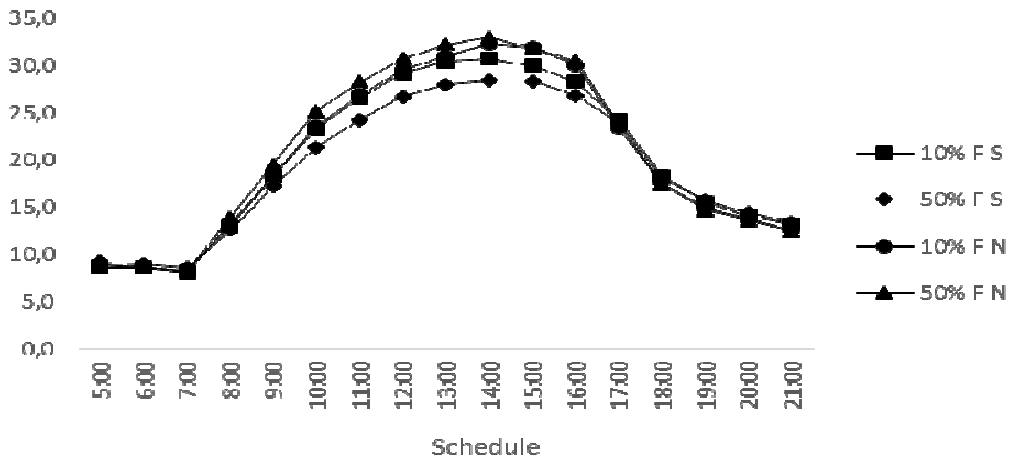

Figure 1. Temperature variation in the shed during the critical winter day with the fibro roof (FN- North; FS - South) with pitches of 10 and $50 \%$

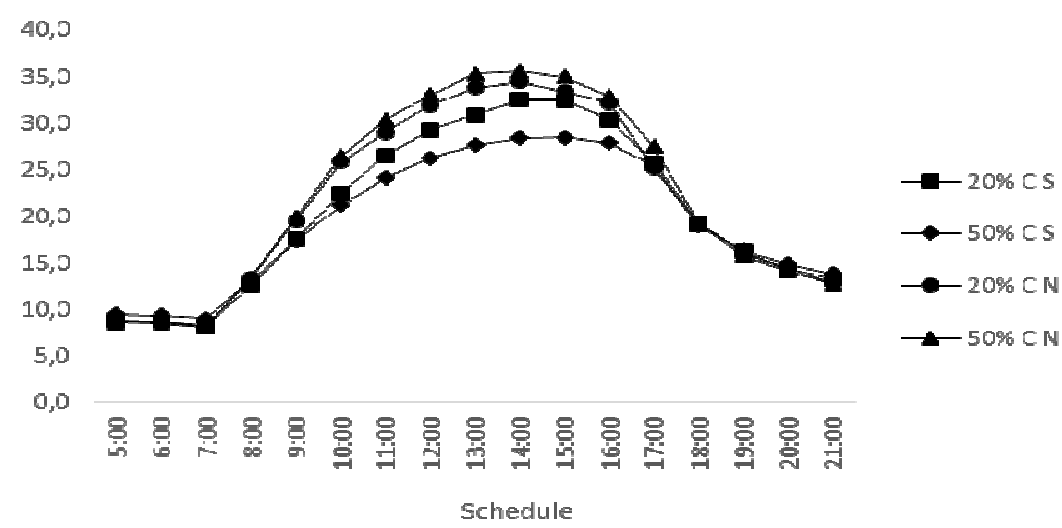

Figure 2. Temperature variation in the shed during the critical winter day with the ceramic roof $(\mathrm{CN}$ - North; CS South) with pitches of 20 and $50 \%$ 


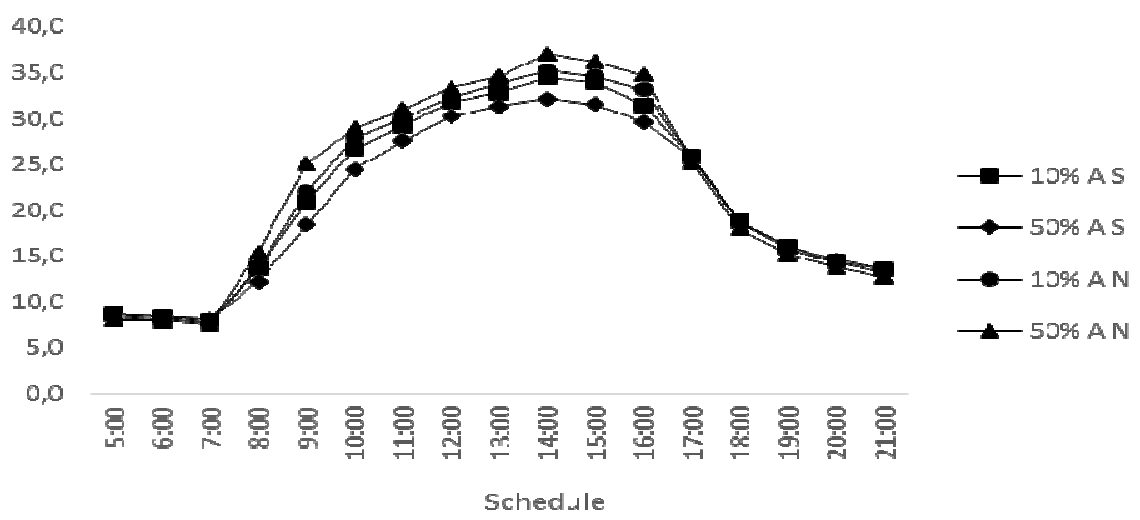

Figure 3. Temperature variation in the shed during the critical winter day with the galvanized-steel roof (AN - North; AS - South) with pitches of 10 and $50 \%$

However, analyzing the temperature variations between the roofing materials, observe that they were not very common on the critical winter day, i.e., there was no difference between roofing materials, except for the galvanized-steel tile.

Regarding the temperature variation during the critical winter days according to the pitches, there were lower temperatures at the pitches of $50 \%$ of ceramic, fibro and galvanized-steel tiles. Solar radiation is a key element in the climatic characterization of regions, because it is the main cause of all meteorological phenomena, at the study site, the estimated average daily values of global solar radiation at the soil level in the fall and winter are 437.0 and $383.3 \mathrm{cal} / \mathrm{cm}^{2} /$ day, respectively (PEDRO JÚNIOR et al., 1989).

No interaction between the roof pitch, exposure and different roofing materials (Table 2). Analyze separately the exposure and the roof pitch, we note (Figure 4 and 5) that as we increase the roof pitch in southern exposure occurred a decrease in the internal temperature of the models both in the fall and winter, corroborating the interaction occurred between the type of roofing material and exposure (Table 3 ), despite hedging and exposure are nested on gradient factor.

By elevating the roof pitch, we modify the height between the apertures for entry and exit of air, thereby affecting the environmental thermal conditioning within the shed, changing the coefficient accordingly to the exchange of heat by radiation between the animal and the roof. Results of improvement in the thermal comfort indices of sheds when the pitch was increased have also been observed by Tinôco (2001). Although the ceramic tiles did not differ statistically from fibro in the present study, results demonstrating the efficiency of the ceramic tiles, in the literature, are plenty (PARKER, 1963; SEVEGNANI et al., 1994; JÁCOME et al. 2007; FURTADO et al., 2003; SANTOS et al., 2005).

The total global solar radiation hitting a surface varies according to the NorthSouth exposure and declivity, demonstrating that one can obtain better thermal performance results in the ceramic and fibro tiles by increasing the pitch with greater exposure to the South when aiming at reducing the temperature, and to the North, to increase it. 
Rev. Bras. Saúde Prod. Anim., Salvador, v.16, n.3, p.658-666 jul./set.., $2015 \quad \underline{\text { http://www.rbspa.ufba.br }}$ ISSN 15199940 http://dx.doi.org/10.1590/S1519-99402015000300016

Table 2. Means of the interaction between Roofing material and Exposure nested with the pitch factor on the internal temperature $\left({ }^{\circ} \mathrm{C}\right)$ in the fall and winter

\begin{tabular}{|c|c|c|c|c|c|c|}
\hline \multicolumn{7}{|c|}{ Fall } \\
\hline & \multicolumn{2}{|c|}{ Ceramic } & \multicolumn{2}{|c|}{ Fibro } & \multicolumn{2}{|c|}{ Galvanized steel } \\
\hline & North & South & North & South & North & South \\
\hline $10 \%$ & - & - & $31.29^{\mathrm{a}}$ & $31.47^{\mathrm{a}}$ & $32.93^{\mathrm{a}}$ & $32.93^{\mathrm{a}}$ \\
\hline $20 \%$ & $32.13^{\mathrm{a}}$ & $31.46^{\mathrm{a}}$ & - & - & - & - \\
\hline $30 \%$ & $32.34^{\mathrm{ab}}$ & $31.12^{b c}$ & $31.56^{\mathrm{bc}}$ & $30.23^{c}$ & $32.92^{\mathrm{a}}$ & $32.78^{\mathrm{ab}}$ \\
\hline $40 \%$ & $32.32^{\mathrm{a}}$ & $30.42^{b c}$ & $31.92^{\mathrm{ab}}$ & $30.28^{c}$ & $33.42^{\mathrm{a}}$ & $32.51^{\mathrm{a}}$ \\
\hline $50 \%$ & $32.55^{\mathrm{ab}}$ & $29.17^{\mathrm{c}}$ & $31.58^{\mathrm{b}}$ & $29.50^{\mathrm{c}}$ & $33.91^{\mathrm{a}}$ & $32.55^{\mathrm{ab}}$ \\
\hline \multicolumn{7}{|c|}{ Winter } \\
\hline & \multicolumn{2}{|c|}{ Ceramic } & \multicolumn{2}{|c|}{ Fibro } & \multicolumn{2}{|c|}{ Galvanized steel } \\
\hline & North & South & North & South & North & South \\
\hline $10 \%$ & - & - & $32.68^{\mathrm{a}}$ & $32.58^{\mathrm{a}}$ & $34.39^{\mathrm{a}}$ & $34.00^{\mathrm{a}}$ \\
\hline $20 \%$ & $33.58^{\mathrm{a}}$ & $32.67^{\mathrm{a}}$ & - & - & - & - \\
\hline $30 \%$ & $33.70^{\mathrm{ab}}$ & $32.28^{\mathrm{bc}}$ & $33.03^{\mathrm{ab}}$ & $31.35^{\mathrm{c}}$ & $34.05^{\mathrm{a}}$ & $33.66^{\mathrm{ab}}$ \\
\hline $40 \%$ & $33.86^{\mathrm{a}}$ & $31.72^{\mathrm{bc}}$ & $33.64^{\mathrm{ab}}$ & $31.59^{\mathrm{c}}$ & $34.96^{\mathrm{a}}$ & $33.73^{\mathrm{a}}$ \\
\hline $50 \%$ & $34.33^{\mathrm{a}}$ & $30.26^{\mathrm{b}}$ & $33.33^{\mathrm{a}}$ & $30.73^{b}$ & $34.55^{\mathrm{a}}$ & $33.63^{\mathrm{a}}$ \\
\hline
\end{tabular}

*Means followed by the same letter within the seasons do not differ statistically according to the Tukey test at $5 \% ; * *$ Lowercase letters for rows.
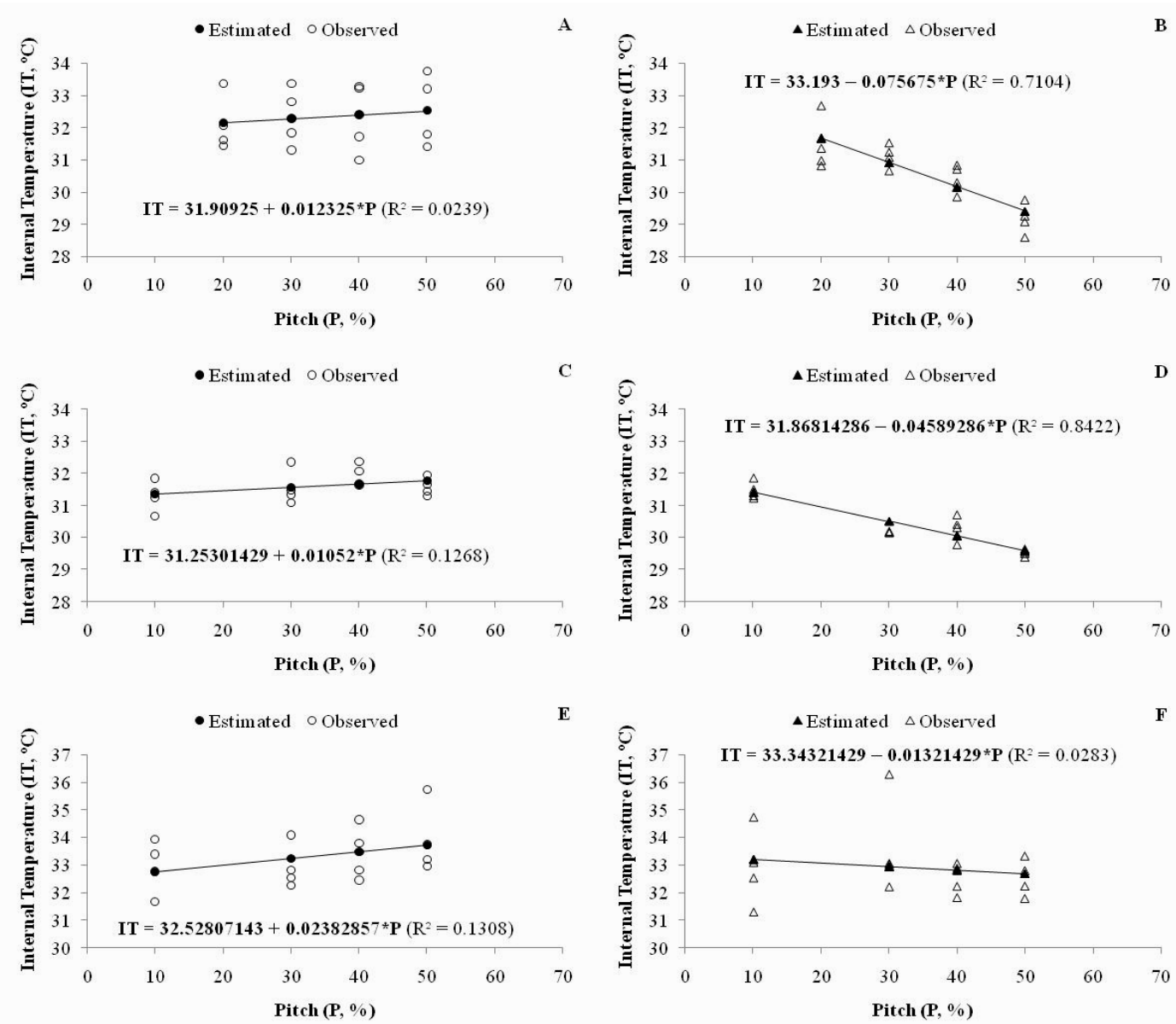

Figure 4. Variation of the internal temperature $\left({ }^{\circ} \mathrm{C}\right)$ in function of pitch factor for the different roofing materials [Ceramic (A and B), Fibro (C and D), and Galvanized steel (E and F)] and exposures [North (A, C and E) and South (B, D and F)] in the Fall season 
Rev. Bras. Saúde Prod. Anim., Salvador, v.16, n.3, p.658-666 jul./set.., $2015 \quad \underline{\text { http://www.rbspa.ufba.br }}$
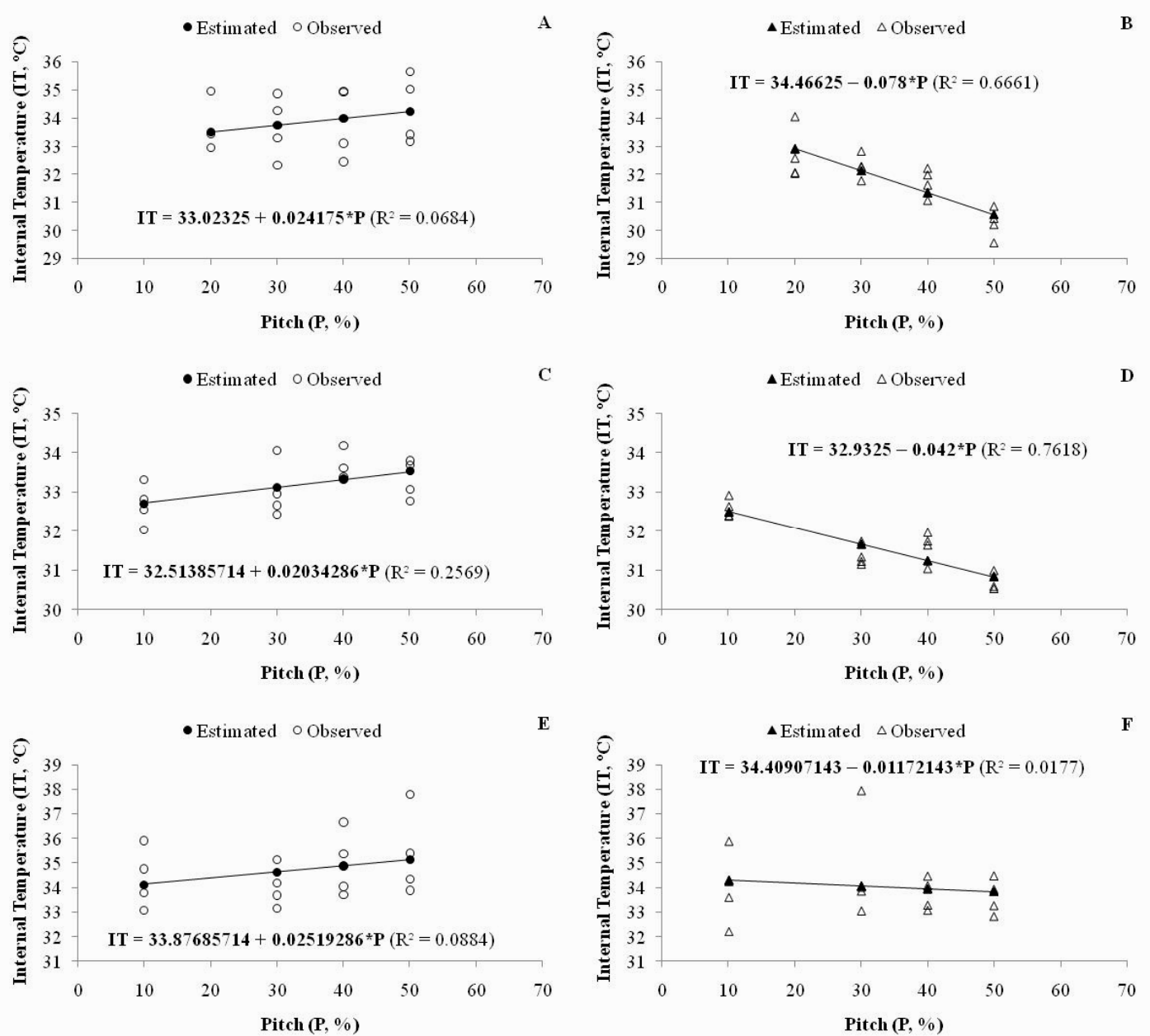

Figure 5. Variation of the internal temperature $\left({ }^{\circ} \mathrm{C}\right)$ in function of pitch factor for the different roofing materials [Ceramic ( $\mathrm{A}$ and $\mathrm{B})$, Fibro $(\mathrm{C}$ and $\mathrm{D})$, and Galvanized steel (E and F)] and exposures [North (A, C and E) and South $(\mathrm{B}, \mathrm{D}$ and $\mathrm{F})]$ in the Winter season

Table 3. Means of the interaction between Roofing Material and Exposure on the internal temperature $\left({ }^{\circ} \mathrm{C}\right)$ of the models during the fall and winter

\begin{tabular}{lcccc}
\hline \multirow{2}{*}{ Materials } & \multicolumn{2}{c}{ Fall } & \multicolumn{2}{c}{ Winter } \\
\cline { 2 - 5 } & North & South & North & South \\
\hline Ceramic & $32.34^{\mathrm{aB}}$ & $30.54^{\mathrm{bB}}$ & $33.87^{\mathrm{aAB}}$ & $31.73^{\mathrm{bB}}$ \\
Fibro & $31.59^{\mathrm{aB}}$ & $30.37^{\mathrm{bB}}$ & $33.17^{\mathrm{aB}}$ & $31.56^{\mathrm{bB}}$ \\
Galvanized steel & $33.30^{\mathrm{aA}}$ & $32.69^{\mathrm{aA}}$ & $34.49^{\mathrm{aA}}$ & $33.76^{\mathrm{aA}}$ \\
\hline
\end{tabular}

*Means followed by the same letter within the seasons do not differ statistically according to the Tukey test at $5 \%$.

**Lowercase letters for rows and uppercase letters for columns.

This feature is best expressed in Table 3 , between roofing material and exposure, due to the inclination of the sun to be more pronounced at these stations. It can be seen that in the southern exposure were presented the lowest mean internal temperature of the reduced models. However, it is worth 
Rev. Bras. Saúde Prod. Anim., Salvador, v.16, n.3, p.658-666 jul./set.., $2015 \quad \underline{\text { http://www.rbspa.ufba.br }}$ ISSN 15199940

stressing that the temperatures observed in the fall and winter seasons were above the thermal-comfort range for poultry (when the internal average temperatures of the models were above $28.0^{\circ} \mathrm{C}$ ), and considering Curtis (1983), who stated that the thermal comfort zone of poultry is between 18 and $28^{\circ} \mathrm{C}$. Therefore, we must be very careful in the hottest seasons and also in the seasons considered less critical (fall and winter), so that animal performance is not impaired. Thus, depending on the dimension and duration of the heat stress suffered by birds, undesirable events such as decrease in weight gain or even prostration and death may occur.

Analyzing the thermal performance of the galvanized-steel roof, the results are most probably due to the higher conductivity of the metallic materials, i.e., metals have a greater capacity of receiving heat or cold, but are also easier to disperse them, so they would heat faster than other materials and consequently get cold faster as well. Despite having more reflectance, the metallic roof showed the highest temperatures, which can be explained by the low emissivity of the material, making its internal environment more uncomfortable. It is possible that the heat-exchange capacity was not obtained at the data collection due to the low air renewal within the model, which probably played a part in the negative result of the galvanized-steel roof. As the roof pitch increased, the internal temperature within the model dropped, so utilizing sharper pitches $(50 \%)$ for ceramic and fibro roofs with a larger area facing the South can provide lower temperatures within the animal production facilities. In regions where the cold is more stressful than the heat, having animal production facilities with larger roof exposure to the North may minimize the losses caused by cold stress.

\section{ACKNOWLEDGEMENTS}

We thanks the São Paulo Research Foundation (FAPESP) for funding this research project and for the fellowship received by Marcos Eli Buzanskas (2013/19335-2).

\section{REFERENCES}

CELIS, J.G.; JARA, J.C. Aplication del analisis dimensional para estimar laventilacíon natural em galpones para aviários. Agro Ciência, v.6, n.1, p.31-36, 1990.

COAN, R.M.; TURCO, J.E.P.; PIVETTA; K.F.L.; COSTA; M.N. da.; MATEUS, C.M. D'A. Emerald zoyzia grass development regarding photo synthetically active radiation in different slopes. Revista Engenharia Agrícola, v.32, n.3, p.501-509, 2012.

\section{CURTIS, S.E. Environmental} management in animal agriculture. Ames: The Iowa State University, 1983. 409p.

FOREHLICH, D.P.; HELLICKSON, M.A.; YOUNG, H.G. Ridge vents effects on model ventilation characteristics.

Transactions of the ASAE, v.18, n.4, p.690-693, 1975.

FURTADO, D.A.; AZEVEDO de, P.V.; TINOCO, I.F.F. Análise do conforto térmico em galpões avícolas com diferentes sistemas de acondicionamento.

Revista Brasileira de Engenharia Agrícola e Ambiental, v.7, n.3, p.559564, 2003. 
Rev. Bras. Saúde Prod. Anim., Salvador, v.16, n.3, p.658-666 jul./set.., $2015 \quad \underline{\text { http://www.rbspa.ufba.br }}$

HANN, L.; BOND, T.E.; KELLY, C.F. Use of models in thermal shades of livestock housing. Transactions of the ASAE, v.4, n.1, p.45-51, 1961.

JÁCOME, I.M.T.D.; FURTADO, D.A.; LEAL, A.F.; SILVA, J.H.V.; MOURA, J.F.P. Avaliação de índices de conforto térmico de instalações para poedeiras no Nordeste do Brasil. Revista Brasileira de Engenharia Agrícola e Ambiental, v.11, n.5, p.527-531, 2007.

PARKER, B.F. Heat transmission caracteristics of sloped roofs exposed to solar radiation. Transactions of the ASAE, v.8, n.1, p.1-5, 1963.

PEDRO JÚNIOR, M.J.; ALFONSI, R.R.; CAMARGO, M.B.P.

Disponibilidade de radiação solar global para o estado de São Paulo. Campinas, SP: Instituto Agronômico de Campinas, 1989. (Boletim Técnico, 123).

SANTOS, P.A. dos; YANAGI JUNIOR, T.; TEIXEIRA, V H. Ambiente térmico no interior de modelos de galpões avícolas em escala reduzida com ventilação natural e artificial dos telhados. Revista

Engenharia Agrícola, v.25, n.3, p.575584, 2005.

SEVEGNANI, K.B.; GHELFI FILHO, H.; SILVA, I.J.O. da. Comparação de vários materiais de cobertura através de índices de conforto térmico. Scientia Agricola, v.51, n.1, p.1-7, 1994.

STATISTICAL ANALISYS SYSTEM -SAS. User's Guide. Version 9.1.

Cary: SAS Institute, 2001. 943 p.
TINÔCO, I.F.F. Avicultura Industrial: Novos Conceitos de Materiais, Concepções e Técnicas Construtivas Disponíveis para Galpões Avícolas Brasileiros. Revista Brasileira de Ciência Avícola, v.3, n.1, p.1-26, 2001.

TURCO, J.E.P.; RIZZATTI, G.S. Avaliação de modelo matemático para estimar a radiação solar incidente sobre superfícies com diferentes exposições e declividades. Revista Engenharia Agrícola, v.26, n.1, p.257-267, 2006.

Data de recebimento: $24 / 04 / 2014$

Data de aprovação: 08/09/2015 